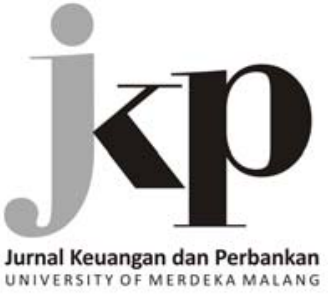

Article history:

Received: 2019-02-12

Revised: 2019-03-23

Accepted: 2019-05-07

Keywords:

Bank profitability; Intellectual capital; Value Added Intellectual Capital (VAIC)

JEL Classification: G21, G32, G32

Kata kunci:

Profitabilitas bank; Modal intelektual; Value Added Intellectual Capital (VAIC)

$\triangle$ Corresponding Author:

Danes Quirira:

Tel. +62 81802066105

E-mail: danes.quirira.fe@um.ac.id

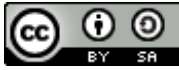

This is an open access article under the CC-BY-SA license

\section{Intellectual capital and bank profitability: Evidence from conventional and Islamic bank in Indonesia}

\author{
Danes Quirira Octavio, Yuli Soesetio \\ Department of Management, Faculty of Economy, State University of Malang \\ Jl. Semarang No.5, Malang, 65145, Indonesia
}

\begin{abstract}
This study investigates the effect of intellectual capital on bank profitability. In addition, we also analyze the effect of intellectual capital on bank profitability based on bank types, conventional and Islamic bank. Our data consist of conventional and Islamic banks operated in Indonesia from 2010 to 2016 annually. Since our data are a panel, we employ panel regression. Intellectual capital is measured by using Value Added Intellectual Capital (VAIC). Our result shows that intellectual capital has a positive significant impact on bank profitability. After data classified based on bank types, intellectual capital only has a positive significant effect on conventional bank profitability. We also attempt to estimate the impact of VAIC components, such as Human Capital Efficiency (HCE), Structural Capital Efficiency (SCE) and Capital Employed Efficiency (CEE), on bank profitability. The results show that the impact of HCE is strongly significant in both banks. However, CEE and SCE do not have a significant effect on both types of bank profitability. Our results indicate that conventional banks synergize their intellectual and physical capital in creating profit better than Islamic banks. Thus, this research could be a critique of the Indonesian Islamic banking industry in determining and overcome their weakness.
\end{abstract}

\begin{abstract}
Abstrak
Studi ini menginvestigasi efek modal intelektual terhadap profitabilitas bank. Sebagai tambahan, kami menganalisa efek modal intelektual terhadap profitabilitas bank dengan mempertimbangkan tipe bank, bank konvensional dan bank Islam. Data kami terdiri dari bank-bank konvensional dan Islam yang beroperasi di Indonesia dari tahun 2010 sampai 2016 secara tahunan. Dikarenakan data ini panel, kami menggunakan regresi panel. Modal intelektual diukur dengan menggunakan pengukuran yang bernama Value Added Intellectual Capital (VAIC). Hasil kami menunjukkan bahwa modal intelektual memiliki pengaruh positif signifikan terhadap profitabilitas bank. Setelah data diklasifikasikan berdasarkan tipe bank, modal intellectual hanya berpengaruh positif signifikan pada profitabilitas bank konvensional. Kami juga mengestimasi dampak komponen VAIC, yaitu Human Capital Efficiency (HCE), Structural Capital Efficiency (SCE), dan Capital Employed Efficiency pada profitabilitas bank. Hasil menunjukkan bahwa HCE secara kuat signifikan pada kedua jenis bank. Akan tetapi, CEE dan SCE tidak memiliki efek signifikan terhadap profitabilitas kedua jenis bank. Hasil ini mengindikasikan bank konvensional dapat mensinergikan modal intelektual dan modal fisiknya lebih baik dalam membuat profit daripada bank Islam. Oleh karena itu, penelitian ini dapat menjadi kritik bagi industri perbankan Islam dalam menentukan dan mengatasi kelemahannya.
\end{abstract}

How to Cite: Octavio, D. Q., \& Soesetio, Y. (2019). Intellectual capital and bank profitability: Evidence from conventional and Islamic bank in Indonesia. Jurnal Keuangan dan Perbankan, 23(2), 191-205. https:/ / doi.org/10.26905/ jkdp.v23i2.3028 


\section{Jurnal Keuangan dan Perbankan}

Volume 23, Issue 2, April 2019: 191-205

\section{Introduction}

In recent years, the knowledge-based resource has been considered as a factor that plays an important role in creating value and achieving superior organizational position (Chahal \& Bakshi, 2016). Information and knowledge had affected the current business environment. As a need to improve, the organization should give more attention to intangible resources (Khan \& Ali, 2010).

Indonesia is a potential market for Islamic banks because the majority of people is Moslem. However, Islamic banks in Indonesia have lacked growth. Indeed, Islamic banking has achieved the target of market share, 5 percent. However, the market share Islamic banking relatively remain stagnant. Some practitioners argue that Islamic banks have inferior management skill compared to conventional banks. Thus, in this study, we focus on investigating the effectiveness of intellectual capital in Islamic conventional banks. Intellectual capital is a concept that the ability of the organization in digging information, organize the data, and using their asset effectively. This concept is mostly in the form of intangible asset and does not show in the financial statement. Intellectual capital may be more essential in Islamic banks, rather than conventional banks since Islamic banking industry finances small micro-enterprises more than conventional banking (Shaban et al., 2014). This activity largely relies on soft information and need a creative method to extract. Thus, intellectual capital may become important to Islamic banks. In addition, Islamic banks investment options are more limited than conventional banks. For example, Islamic banks cannot invest their funds in derivative asset since it is considered as gambling based on sharia law. Thus, intellectual capital plays an important role in creating competitive advantage, especially in Islamic banks.

Our study focuses on the impact of intellectual capital application in the banking industry since intellectual capital is more crucial in the banking in- dustry than any other industries. Banking industry uses a lot of intangible assets for its operation and survival and it is highly service-oriented industry (Meles et al., 2016). Nevertheless, most empirical intellectual capital studies only focus on conventional or Islamic banks only or never considered its type. Thus, in this study, we attempt to include conventional banks and Islamic banks. By examining both, we could compare and understand whether any differences in intellectual capital applied between them.

In this study, we examine the effect of intellectual capital on banks profitability. Our sample is 102 conventional banks and 12 Islamic banks operated in Indonesia between 2010 and 2016. That length of the period is chosen since there is no crises existence. VAIC developed by Pulic (1998) is chosen to measure intellectual capital since this indicator is widely recognized as an intellectual capital measurement in many intellectual capital studies. Generally, several significant positive effects between VAIC and profitability were occurred (Ting \& Lean, 2009; Mondal \& Ghosh, 2012; Ousama \& Fatima, 2015; Nawaz \& Haniffa, 2017). However, some insignificant findings were also founded (Rehman et al., 2012; Ozkan, Cakan, \& Kacayan, 2017; Puntillo, 2009). In addition, some studies investigate the relationship between VAIC components and profitability have been conducted. The components are Human Capital Efficiency (HCE), Structural Capital Efficiency (SCE), and Capital Employed Efficiency (CEE). Based on previous studies, HCE has mostly had a stronger effect on profitability compared to other components. Indeed, some studies have found some exception. Ozkan, Cakan, \& Kacayan (2017) using data of 44 Turkey banks found that there was no significant effect between VAIC and return on asset. Puntillo (2009), using data of 21 banks listed in the Italian Stock Exchange, found that only CEE that has a positive impact on Return on Asset (ROA).

This research has a contribution to Islamic economics by examining the behavior of Islamic 
banking. Based on Susamto (2018), our study has a contribution to Islamic economics by evaluating the actual behavior of Islamic banks in managing their intellectual capital and compare it to the behavior of conventional banks. Thus, our study can be advised to move the behavior of Islamic banks to be closer to its ideal. In addition, the number of studies using conventional and Islamic banks data and comparing the result is relatively limited. In addition, most of the studies of intellectual capital only analyze either Islamic banks, conventional banks, or never care about its types.

Our study consists of five sections. The first section reveals the importance of this study. The second section explains the concept of intellectual capital and reviews some intellectual capital literature. The third section explains the data, variables, and methods. In the fourth section, the empirical results are reviewed. The fifth section discusses the result and its contribution. The last section concludes the result and future agenda related to the intellectual capital topic.

\section{Hypotheses Development}

In the last decade, intellectual capital has considered as an important driver in creating added value for the firms. However, intellectual capital is often shown as intangible assets and is not shown on the balance sheet explicitly. Thus, researchers have tried to take identify the element that formed intellectual capital. Then, it's lead to too many varieties of definitions. Take for example Garcia-Meca \& Martinez (2005) proposed that intellectual capital consists of knowledge, information, intellectual property and experience that can create wealth. Bayburina \& Golovko (2009) explained that intellectual capital includes human capital, process capital, client capital, innovation capital, and network capital. (Bontis, 1999) defined intellectual capital as a set human capital, relational capital, and structural capital.
Human capital is defined as a collection of individual or employees' knowledge, skills, and expertise that formed organization character (Bontis, 1999). It is the main source of innovation and strategic renewal within the organization. Structural capital presents the mechanism and organization structures that support employee to generate their optimum performance and thus enhance an organization's competitive advantage (Bontis, 1999). Databases, organization chart, management processes, procedures, and business strategies are items related to structural capital. Structural capital can be referred to as an activity that has been planned and usually tends to have repetitive traits. Relational Capital (RC) is the complex relationship between the organization and the external world (Meles et al., 2016). RC refers to all intangible assets, which regulate and manage the relationships of an organization. It comprises the organization's relationships with its customers, suppliers, shareholders and other stakeholders (Ozkan, Cakan, \& Kacayan, 2017).

However, there is no measurement that can represent those three elements perfectly. The indicators expressing intellectual capital tend to apply subjective judgment (Pulic, 1998). Thus, Pulic (1998) proposed indicators that can minimize the bias, namely Value Added Intellectual Coefficient (VAIC). Based on the operational definition, VAIC calculates the contribution of human capital, structural capital, and physical capital in creating value-added for the firm. It changes relational capital to physical capital because physical capital can be expressed and calculated in monetary terms easier than relational capital. Physical capital has an important role in creating value-added because it helps human capital and structural capital to perform well. Firms that have better physical capital can provide more facilities and utilities to support the employee in applying their knowledge and procedures. Nowadays, VAIC is widely accepted in almost every intellectual capital empirical studies in measuring intellectual capital. 
Public's concept of intellectual capital also aligns with the resource-based view. Resource-based view sees the exploitation of physical capital in the firm needs socially complex resources. Firms that possess this socially complex resources can fully exploit their physical capital efficiently more than other firms. These socially complex resources are intangible asset associated with culture, knowledge, social relations, business strategy, etc.

There are a lot of studies that have conducted by various researchers. In 2012, using 65 Indian Banks data, Mondal \& Ghosh (2012) conducted crosssection regression for each research year period, from 1998 to 2008. Mondal \& Ghosh (2012) found that the effect of VAIC on ROA was relatively stable in every research period. Similar to Mondal \& Ghosh (2012). Ting \& Lean (2009) found that VAIC has a positive effect on the ROA in Malaysia. However, this study did not consider the type of bank such as conventional and Islamic. Thus, Ousama \& Fatima (2015) expanded the study by examining the effect of VAIC on return on an asset in Malaysia Islamic banks. They found that VAIC had a positive effect on return on asset and return on equity. They also found that all components VAIC had a positive effect on return on equity, while only CEE that had a positive effect on return on asset. Nawaz \& Haniffa (2017) expand the study of the impact of VAIC on Islamic bank performance by enlarging the data using Islamic banks from 18 different countries. They found that VAIC has a positive significant effect on Islamic bank return on asset. In addition, they also analyze the impact of the intellectual capital component on its return to the asset. They found that HCE and CEE have a positive significant effect on ROA, while CEE has no effect on ROA. Khairiyansyah \& Vebtasvili (2018) investigated the impact of VAIC component on the ROA of the bank that listed on the Indonesia Stock Exchange. They found that all component has a positive significant effect on ROA. Using 5749 annually US banks from 2005 to 2012,
Meles et al. (2016) found that VAIC had a positive effect on return on average assets and return on average equity.

Some studies have found other results regarding the correlation between VAIC and bank profitability Ozkan, Cakan, \& Kacayan (2017) using data of 44 Turkey banks found that there was no significant effect between VAIC and ROA. For VAIC components, only HCE and CEE had a positive effect on ROA. This result was similar to Rehman et al. (2012). Using data of 30 Pakistan banks, they also not found any correlation between VAIC and ROA. Puntillo (2009), using data of 21 banks listed in the Italian Stock Exchange, found only CEE that has a positive impact on ROA.

Based on previous empirical studies, they were mostly only focused on one type of bank, neither Islamic nor conventional banks only or did not consider the type of bank. Thus, we try to fill the gap by investigating the impact of intellectual capital on Islamic banks and conventional banks simultaneously. In this research, we investigate the relationship of intellectual capital and it's componentbased on VAIC on bank profitability in Islamic bank and conventional banks located in Indonesia.

In this research, besides analyzing the relationship of VAIC and its component on bank profitability, we also investigate the differences of VAIC and its component between Islamic bank and conventional banks located in Indonesia. Based on the phenomenon and current debates, some hypotheses are able to be formulated:

$\mathrm{H}_{1}$ : the value-added intellectual capital coefficient (VAIC) has a positive effect on return on asset

$\mathrm{H}_{2}$ : human capital efficiency coefficient (HCE) has a positive effect on return on asset (ROA)

$\mathrm{H}_{3}$ : structural capital efficiency coefficient (SCE) has a positive effect on return on asset (ROA)

$\mathrm{H}_{4}$ : capital employed efficiency coefficient (CEE) has a positive effect on return on asset (ROA) 


\section{Method, Data, and Analysis}

Our sample consists of Islamic banks and conventional banks, both are listed and unlisted in the capital market, operated in Indonesia. In this study, we only examine banks that are still operating in Indonesia. There are 114 banks, 102 conventional banks, and 12 Islamic banks. It is collected from the Financial Services Authority of Indonesia (OJK). Our data are unbalanced and collected annually between 2010 and 2016. This period is chosen because there was no crisis occurred. The total observations are 793 observations, 713 for conventional banks and 80 for Islamic banks. However, we found some odd in conventional banks. There are some conventional banks have zero loan loss provision. Based on data, we found that four foreign conventional banks have zero loan loss provision in some particular period. Our finding aligns with the Financial Services Authority (OJK) since they have asked the foreign bank to give more contribution to the Indonesia economy. Thus, we exclude data which have zero loan loss provision. The total of final samples is 776 observations, 696 for conventional banks and 80 for Islamic banks.

Multiple regression analysis is undertaken to investigate the effect of VAIC and its component on profitability. Not only pooled OLS, but the fixed effect is also conducted to check the stability of the result. Fixed effect estimation is shown since we consider the weakness of OLS in panel data. In panel data, there is a repeating cross-section in each period. The characteristic of each individual cross-section is not considered in OLS estimation. Thus, the estimation will become inefficient. In other words, it increases the error of estimation. To increase the efficiency of the model estimation, the error needs to be minimized. Fixed effect attempt to reduce the error by assuming the cross-section characteristic that repeated in each period is the same. Thus, error (e) is able to be classified into two classifications, error time-invariant (v) and idiosyncratic er- ror $(\mu)(2)$. Since the value of error time-invariant is not change for each period unless, in different individual cross-section, it can be negated by subtracting it to the mean of error time-invariant itself. As the consequences, all of the variables and idiosyncratic error needs to be subtracted by its mean value (3). In addition, to increase the efficiency of the model, the robust standard error will be computed

$Y_{i t}=\beta X_{i t}+e_{i t}$

$Y_{i t}=\beta X_{i t}+\mu_{i t}+v_{i}$

$Y_{i t}-\bar{Y}_{i}=\beta\left(X_{i t}-\bar{X}_{i}\right)+\mu_{i t}-\bar{\mu}_{i}+v_{i}-\bar{v}_{i}$

on each model (Le \& Phan, 2017).

$\mathrm{Y}$ denotes dependent variable, $\mathrm{X}$ denotes independent variable, $\beta$ denotes coefficient value, $\mathrm{e}$ denotes error, $\mu$ denotes idiosyncratic error, $v$ denotes error time-invariant.

Our dependent variable is Return on Asset (ROA) ratio. This variable reflects bank profitability. It generates the ratio of net income to the total asset. This ratio measures the ability of a firm in generating income on a certain level of the total asset it had.

$R O A_{i, t}=\frac{\text { Net income }}{\text { Total asset }}$

Our main independent variables are intellectual capital and components of intellectual capital. Intellectual capital is measured by Value added intellectual capital (VAIC). This measurement is founded by Pulic (1998). VAIC, is composed of threecomponent. They are human capital efficiency (HCE), structural capital efficiency (SCE) and capital employed efficiency (CEE). This component also included separately with VAIC as main independent variables since VAIC measures all whole components in one measurement. By examine it separately, we could found which component is more important in creating bank profitability. 
$V A I C_{i . t}=H C E+S C E+C E E$

In order to calculate and its components, the total value added (VA) is needed to be calculated first. is the organization's ability to in creating valueadded. It is calculated as the difference between output (OUT) and input (INT). The output is the total revenue generated by the services provided by the bank to the clients and the input is all the expenses occurred during the production minus personnel expense.

$V A=O U T-I N T$

Human capital efficiency (HCE) is defined as the contribution of one unit of human capital expenses on value-added. The human capital expenses (HC) based on the bank's overall payroll.

$H C E=\frac{V A}{H C}$

The second component is structural capital efficiency (SCE). This phase measures the contribution of structural capital (SC) in generating valueadded. SC is calculated by subtracting HC from VA. Here is the formula:

$S C=V A-H C$

$S C E=\frac{S C}{V A}$

The last component, capital employed efficiency (CEE) represents the contribution of the tangible asset on bank value-added. Having good tangible asset (physical and financial asset), intellectual capital will perform more effective and efficient, for example, the bank that has good computer server can reduce the number of error then increase customers satisfaction in transferring their money. In this formula, refers to the sum of the physical and financial capital of the banks. Here is the formula of calculating CE and CEE:
$C E=$ Phisycal Asset + Financial Asset

$C E E=\frac{V A}{C E}$

To prevent omitted variable bias, control variables are included. Those variables consist of two categories, such as bank-level variables and macroeconomic variables. Bank-level variables are banks size, capital ratio, loan loss provision ratio, loan ratio, and bank efficiency. Inflation and growth of gross domestic product are macroeconomic variables.

Bank size is measured as the natural logarithm of banks total asset (LnTA). Bank with large size has economic of scale, reducing its cost significantly (Goddard, Molyneux, \& Wilson, 2004). Thus, we expect bank size has a positive effect on bank profitability. The capital ratio is measured by equity to the total asset (CAP), reflects additional power of the bank to face financial crises or unstable macroeconomic condition (Menicucci \& Paolucci, 2016). Well capitalized banks tend to have less cost of capital, causing a positive effect on bank profitability. Loan loss provision (LLP) shows how much expense set aside as an allowance for uncollected loans relative to its total loans. In other words, this ratio reflects the bank's loan portfolio quality. The high number of this ratio indicates a higher risk of the loan portfolio and, therefore, lowering its profitability. Thus, we expect loan loss provision ratio negatively affect bank profitability. Total loan to total asset or famously called a loan ratio (LOANTA) is a ratio that reflects the ability of the bank to fulfill the loan relative to its total asset. The impact of loan ratio on bank profitability is very difficult to predict. Higher loan ratio may lead to higher credit risk and, therefore, reduces its profitability. However, a bank with high loan ratio may have a high profit as the consequences of the added business activity. Even though this variable has no steady impact direction on bank profitability, we still include this variable to avoid omitted variable bias. 
For macroeconomic variables, inflation (INF) and the growth of gross domestic product (GrGDP) are included in our models. Demirguc-Kunt \& Huizinga (2000) identified that the business cycle can be reflected by the growth of the gross domestic product. They found the growth of gross domestic product has a positive association with bank profitability. For inflation, it has no fix association with bank profitability. Some studies found that there is a positive association with bank profitability (Demirguc-Kunt \& Huizinga, 2000; Tan \& Floros, 2012), while others found a reversed result (Sufian \& Chong, 2008).

Based on the dependent, independents and control variables that we explained in previous paragraphs, regression models are able to be formulated. There is six models in this study. To understand the effect of VAIC and its component in all bank types, only conventional and only Islamic banks, we modify the sample inputted in regression.

$$
\begin{aligned}
\text { ROA }_{i t}= & \text { Alpha }+\beta_{1} \text { VAIC }_{i t} \\
\text { ROA }_{i t}= & \text { Alpha }+\beta_{1} \text { VAIC }_{i t}+\beta_{2} \text { LLP }_{i t}+\beta_{3} \\
& \text { LOANTA }_{i t}+\beta_{4} \text { CAP }_{i t}+\beta_{5} \text { LnTA }_{i t}
\end{aligned}
$$

$$
\begin{aligned}
& R O A_{i t}=\text { Alpha }+\beta_{1} \text { VAIC }_{i t}+\beta_{2} L L P_{i t}+\beta_{3} \\
& \text { LOANTA }_{i t}+\beta_{4} C A P_{i t}+\beta_{5} \operatorname{LnTA}_{i t}+\beta_{6} \\
& \mathrm{GrGDP}_{t}+\beta_{7} I N F_{t} \\
& R O A_{i t}=\text { Alpha }+\beta_{1} H C E_{i t}+\beta_{2} S C E_{i t}+\beta_{3} C E E_{i t}(15) \\
& R O A_{i t}=\text { Alpha }+\beta_{1} H C E_{i t}+\beta_{2} S C E_{i t}+\beta_{3} C E E_{i t}+\beta_{4} \\
& L L P_{i t}+\beta_{5} \text { LOANTA }_{i t}+\beta_{6} \text { CAP }_{i t}+\beta_{7} \\
& \operatorname{LnTA}_{i t} \\
& R O A_{i t}=\text { Alpha }+\beta_{1} H C E_{i t}+\beta_{2} S C E_{i t}+\beta_{3} C E E_{i t}+\beta_{4} \\
& L L P_{i t}+\beta_{5} L_{\text {LANTA }}+\beta_{6} \text { CAP }_{i t}+\beta_{7} \\
& \operatorname{LnTA}_{i t}+\beta_{8} \mathrm{GrGDP}_{t}+\beta_{9} I N F_{t}
\end{aligned}
$$

\begin{tabular}{|c|c|c|c|c|c|c|c|c|c|c|c|}
\hline \multirow[b]{2}{*}{ Variable } & \multicolumn{5}{|c|}{ Conventional Banks } & \multicolumn{5}{|c|}{ Islamic Banks } & \multirow[b]{2}{*}{ z-test } \\
\hline & Obs & Mean & $\begin{array}{l}\text { Std. } \\
\text { Dev. }\end{array}$ & Min & $\operatorname{Max}$ & Obs & Mean & $\begin{array}{l}\text { Std. } \\
\text { Dev. }\end{array}$ & Min & $\operatorname{Max}$ & \\
\hline ROA & 696 & 0.013 & 0.015 & -0.117 & 0.053 & 80 & 0.004 & 0.027 & -0.169 & 0.056 & $5.752 * * *$ \\
\hline LLP & 696 & 0.021 & 0.032 & $3.84 * 10^{-6}$ & 0.613 & 80 & 0.033 & 0.057 & 0.009 & 0.414 & $-5.535^{\star * *}$ \\
\hline LOANTA & 696 & 0.634 & 0.108 & 0.092 & 0.880 & 80 & 0.685 & 0.123 & 0.082 & 0.890 & $-5.525^{* * *}$ \\
\hline CAP & 696 & 0.150 & 0.094 & -0.006 & 0.888 & 80 & 0.167 & 0.124 & 0.055 & 0.613 & 1.103 \\
\hline VAIC & 696 & 2.840 & 2.387 & -22.40 & 18.45 & 80 & 2.731 & 3.687 & -11.61 & 29.30 & $1.745^{*}$ \\
\hline HCE & 696 & 2.313 & 1.943 & -16.06 & 17.47 & 80 & 1.759 & 2.124 & -12.52 & 6.400 & $2.491^{* *}$ \\
\hline SCE & 696 & 0.475 & 1.170 & -22.45 & 11.77 & 80 & 0.931 & 3.284 & -0.127 & 29.34 & 1.008 \\
\hline CEE & 696 & 0.051 & 0.261 & -0.126 & 5.382 & 80 & 0.040 & 0.044 & -0.169 & 0.181 & -0.544 \\
\hline LnTA & 696 & 16.22 & 1.712 & 11.797 & 20.68 & 80 & 15.66 & 1.334 & 12.727 & 18.18 & $2.897^{* * *}$ \\
\hline GrGDP & 696 & 0.056 & 0.005 & 0.049 & 0.065 & 80 & 0.056 & 0.005 & 0.049 & 0.065 & 0.176 \\
\hline INF & 696 & 0.054 & 0.022 & 0.030 & 0.083 & 80 & 0.054 & 0.022 & 0.030 & 0.083 & 0.043 \\
\hline
\end{tabular}

\section{Results}

\section{Statistic descriptive and correlation matrix}

Our statistic descriptive shows the mean, standard deviation, minimum value, maximum value, and Mann-Whitney z-test result. This descriptive statistic shows the basic profiles and differences between conventional and Islamic banks data. Before we compare the profile of conventional and Islamic banks,

Table 1. Statistic descriptive 
Overall, the performance indicators show that conventional banks have outperformed Islamic banks. Based on return on asset, the value of average return on asset of conventional banks surpasses Islamic banks significantly. The average value of loan loss provision of conventional banks is also significantly less than Islamic banks. It indicates that the quality of conventional banking industry loan is better than the Islamic banking industry. The average value of loan ratio of Islamic banks strongly exceeds conventional banks. It means Islamic banks have more courage to put their asset more on credit. Our statistic descriptive also shows that the average value of $\ln$ total asset of conventional banks is significantly bigger than Islamic banks. For the intellectual capital indicators, VAIC and HCE show a significant difference between Islamic and conventional banks. Its show that conventional banks, on the average, have VAIC and HCE higher than Islamic banks.

In addition, we also show the correlation matrix of each independent variables in order to show that there is no multicollinearity. Since we conduct two regressions based on the type of banks, conventional and Islamic banks, we also divide our correlation matrix into two categories. We also omit the correlation of VAIC on its component since by definition, the correlation of VAIC on its compo- nent, HCE, SCE, and CEE, must have a correlation. To make our table more efficient, we show two correlation matrixes on one table. The correlation matrix of conventional banks data is shown in the bold letter, while Islamic banks are in the italic letter. Our result shows that there is no value of more than 0.800 . Thus, we can conclude that there is multicollinearity on each independent variable.

\section{Regression Analysis}

In these regression analyses, the fixed effect is chosen because our data is a panel. By using this method, we can minimize error time-invariant compared to ordinary least square (OLS). However, we also show the result using the OLS method to check the result consistency and stability. In this study, we classify the analysis into two, full sample and split the sample by bank type.

Table 3 shows the impact of VAIC on ROA in Indonesia banking industry. VAIC has a positive effect on return on asset. The results show that the effect of VAIC remain positive significant ( $p$-value $<0.01$ ), though macroeconomic and bank-specific variables have included. When the OLS method is applied, the level of significance of VAIC is increased.

Table 2. Correlation matrix

\begin{tabular}{|c|c|c|c|c|c|c|c|c|c|c|}
\hline & LLP & LOANTA & CAP & VAIC & $\mathrm{HCE}$ & SCE & CEE & LnTA & GrGDP & INF \\
\hline LLP & 1 & 0.134 & 0.292 & -0.418 & -0.726 & 0.009 & -0.600 & -0.113 & -0.199 & -0.192 \\
\hline LOANTA & -0.026 & 1 & -0.432 & -0.341 & -0.300 & -0.187 & -0.176 & 0.509 & -0.405 & -0.025 \\
\hline CAP & -0.082 & -0.256 & 1 & 0.158 & 0.032 & 0.157 & -0.070 & -0.638 & 0.171 & -0.025 \\
\hline VAIC & -0.060 & 0.141 & -0.090 & 1 & 0,47 & 0.815 & 0.259 & -0.225 & 0.298 & 0.168 \\
\hline HCE & -0.094 & 0.147 & -0.098 & 0.865 & 1 & -0.128 & 0.662 & 0.028 & 0.238 & 0.220 \\
\hline SCE & 0.036 & 0.031 & -0.021 & 0.568 & 0.094 & 1 & -0.151 & -0.271 & 0.180 & 0.045 \\
\hline CEE & -0.005 & 0.047 & 0.000 & 0.155 & 0.050 & 0.010 & 1 & 0.046 & 0.113 & 0.149 \\
\hline LnTA & 0.152 & 0.149 & -0.460 & 0.225 & 0.246 & 0.050 & -0.001 & 1 & -0.293 & -0.048 \\
\hline GrGDP & 0.050 & -0.166 & -0.034 & 0.054 & 0.058 & 0.022 & -0.037 & -0.186 & 1 & 0.171 \\
\hline INF & -0.021 & 0.032 & -0.048 & 0.049 & 0.065 & 0.002 & -0.045 & -0.041 & 0.172 & 1 \\
\hline
\end{tabular}

LLP denotes loan loss provision, LOANTA denotes loan to total asset, CAP denotes equity to total asset, VAIC denotes value-added intellectual capital, HCE denotes human capital efficiency, SCE denotes structural capital efficiency, CEE denotes capital employed efficiency LnTA denotes natural logarithm of total asset, GrGdp denotes growth of gross domestic product, and INF denotes inflation rate. 
Besides, we also analyze the effect of VAIC on ROA based on bank classification, conventional and Islamic banks. Thus, we split our sample based on bank type. The fixed effect is chosen since it can reduce time-invariant error. The results are shown in Table 4. Based on that table 4, the effect of VAIC on conventional banks ROA remains positive significant ( $\mathrm{p}$-value $<0.01$ ), though macroeconomic and bank-specific variables have included. For control variables, INF and GrGDP have a strong positive effect on ROA. Contrast to conventional banks, the effect of VAIC on ROA in Islamic banks is not significant in every test. In addition, LLP and LOANTA have a negative effect on ROA, while LnTA and
GrGDP have positive ones.

In order to determine the specific component of intellectual capital which has an impact on Indonesia banking profitability, we conduct several regressions. Table 5 shows the effect of VAIC components on ROA of Indonesia banks. Similar to the previous test, fixed effect and OLS is applied. The result of table 5 shows that only HCE is the most important element of VAIC in generating profit ( $\mathrm{p}$ value $<0.01$ ). The result is strong since the effect of HCE is consistent in every model. Another component has no significant effect. For the control variable, GrGDP has a consistent positive significant effect on profitability.

Table 3. Regression result: the effect of VAIC on bank profitability

\begin{tabular}{|c|c|c|c|c|c|c|}
\hline \multirow[b]{3}{*}{ Variables } & \multicolumn{3}{|c|}{$\begin{array}{c}\text { Conventional \& Islamic Banks } \\
\text { Fixed Effect }\end{array}$} & \multicolumn{3}{|c|}{$\begin{array}{c}\text { Conventional \& Islamic Banks } \\
\text { OLS }\end{array}$} \\
\hline & (1) & (2) & (3) & (1) & $(2)$ & (3) \\
\hline & ROA & ROA & ROA & ROA & ROA & ROA \\
\hline \multirow[t]{2}{*}{ VAIC } & $0.003^{* *}$ & $0.002^{* *}$ & $0.002^{* *}$ & $0.003^{* * *}$ & $0.003^{* * *}$ & $0.003^{* * *}$ \\
\hline & $(0.001)$ & $(0.001)$ & $(0.001)$ & $(0.001)$ & $(0.001)$ & $(0.001)$ \\
\hline \multirow[t]{2}{*}{ LLP } & & -0.167 & -0.159 & & $-0.151^{* *}$ & $-0.155^{* *}$ \\
\hline & & $(0.129)$ & $(0.120)$ & & $(0.068)$ & $(0.066)$ \\
\hline \multirow[t]{2}{*}{ LOANTA } & & -0.006 & 0.001 & & $-0.013^{* *}$ & -0.008 \\
\hline & & $(0.012)$ & $(0.011)$ & & $(0.006)$ & $(0.005)$ \\
\hline \multirow[t]{2}{*}{ CAP } & & -0.006 & $0.020^{*}$ & & -0.013 & -0.007 \\
\hline & & $(0.008)$ & $(0.012)$ & & $(0.009)$ & $(0.009)$ \\
\hline \multirow[t]{2}{*}{ LnTA } & & $-0.003^{* *}$ & 0.006 & & $0.001^{* * *}$ & $0.002^{* * *}$ \\
\hline & & $(0.001)$ & $(0.004)$ & & $(0.000)$ & $(0.000)$ \\
\hline \multirow[t]{2}{*}{ GrGDP } & & & $0.802^{* * *}$ & & & $0.519 * * *$ \\
\hline & & & $(0.284)$ & & & $(0.093)$ \\
\hline \multirow[t]{2}{*}{ INF } & & & $0.042^{* * *}$ & & & $0.037^{*}$ \\
\hline & & & $(0.016)$ & & & $(0.020)$ \\
\hline \multirow{2}{*}{ Constant } & 0.004 & $0.060 * * *$ & -0.133 & 0.003 & -0.003 & $-0.046^{* * *}$ \\
\hline & $(0.004)$ & (0.019) & $(0.082)$ & $(0.002)$ & $(0.009)$ & (0.011) \\
\hline R-square & 0.238 & 0.369 & 0.415 & 0.228 & 0.351 & 0.378 \\
\hline Observations & 776 & 776 & 776 & 776 & 776 & 776 \\
\hline Number of Bank & 116 & 116 & 116 & 116 & 116 & 116 \\
\hline
\end{tabular}




\section{Jurnal Keuangan dan Perbankan}

Volume 23, Issue 2, April 2019: 191-205

Similar to the previous test, we also examine the effect of VAIC components on bank profitability based on bank types. The fixed effect is conducted in this analysis. The result of table 6 shows that HCE is the most important element of VAIC, both for conventional and Islamic banks in generating profit ( $\mathrm{p}$-value $<0.01$ ). Another component has no effect on bank profitability. There is no consistent significant effect of bank-level control variables in conventional banks. However, one of the banklevel control variable, LLP, has a consistently significant effect on Islamic banks profitability. Our finding also finds that INF and GrGDP have a significant effect on the profitability of the conventional bank, while INF is only had a significant effect on the profitability of Islamic banks.

\section{Discussion}

Our finding finds that Islamic banks relatively lack intellectual capital. In addition, comparing to conventional banks, Islamic banks lack the ability to effectively manage intellectual capital as a resource to create value creation. Using all banks data, human capital is the most significant component of intellectual capital that create bank profitability in Indonesia. If we classify the data into conventional and Islamic banks, human capital is still a dominant

Table 4. Split sample regression result: the effect of VAIC on bank profitability

\begin{tabular}{|c|c|c|c|c|c|c|}
\hline \multirow[b]{2}{*}{ Variables } & \multicolumn{3}{|c|}{$\begin{array}{c}\text { Conventional Banks } \\
\text { Fixed Effect } \\
\end{array}$} & \multicolumn{3}{|c|}{$\begin{array}{l}\text { Islamic Banks } \\
\text { Fixed Effect }\end{array}$} \\
\hline & $\begin{array}{c}(1) \\
\text { ROA }\end{array}$ & $\begin{array}{c}\text { (2) } \\
\text { ROA }\end{array}$ & $\begin{array}{c}(3) \\
\text { ROA }\end{array}$ & $\begin{array}{c}(1) \\
\text { ROA }\end{array}$ & $\begin{array}{c}\text { (2) } \\
\text { ROA }\end{array}$ & $\begin{array}{c}(3) \\
\text { ROA } \\
\end{array}$ \\
\hline VAIC & $\begin{array}{r}0.003^{* * *} \\
(0.001)\end{array}$ & $\begin{array}{r}0.003^{* * *} \\
(0.001)\end{array}$ & $\begin{array}{r}0.003^{* * *} \\
(0.001)\end{array}$ & $\begin{array}{r}0.003 \\
(0.004)\end{array}$ & $\begin{array}{r}0.000 \\
(0.001)\end{array}$ & $\begin{array}{r}0.001 \\
(0.001)\end{array}$ \\
\hline LLP & & $\begin{array}{r}-0.026 \\
(0.071)\end{array}$ & $\begin{array}{r}-0.028 \\
(0.067)\end{array}$ & & $\begin{array}{r}-0.433^{* * *} \\
(0.051)\end{array}$ & $\begin{array}{r}-0.392^{* * *} \\
(0.050)\end{array}$ \\
\hline LOANTA & & $\begin{array}{r}0.009 \\
(0.008)\end{array}$ & $\begin{array}{r}0.013 \\
(0.009)\end{array}$ & & $\begin{array}{r}-0.047^{* *} \\
(0.019)\end{array}$ & $\begin{array}{l}-0.039^{*} \\
(0.019)\end{array}$ \\
\hline CAP & & $\begin{array}{l}-0.011 \\
(0.008)\end{array}$ & $\begin{array}{r}0.005 \\
(0.009)\end{array}$ & & $\begin{array}{r}0.004 \\
(0.023)\end{array}$ & $\begin{array}{r}0.032 \\
(0.034)\end{array}$ \\
\hline LnTA & & $\begin{array}{r}-0.005^{* * *} \\
(0.001)\end{array}$ & $\begin{array}{r}0.001 \\
(0.002)\end{array}$ & & $\begin{array}{r}0.006 \\
(0.004)\end{array}$ & $\begin{array}{r}0.017^{* * *} \\
(0.004)\end{array}$ \\
\hline GrGDP & & & $\begin{array}{r}0.468^{* * *} \\
(0.160)\end{array}$ & & & $\begin{array}{r}1.082^{* * *} \\
(0.293)\end{array}$ \\
\hline INF & & & $\begin{array}{r}0.036^{* * *} \\
(0.010)\end{array}$ & & & $\begin{array}{l}-0.021 \\
(0.028)\end{array}$ \\
\hline Constant & $\begin{array}{r}0.005^{*} \\
(0.003)\end{array}$ & $\begin{array}{r}0.077^{* * *} \\
(0.016)\end{array}$ & $\begin{array}{r}-0.040 \\
(0.045)\end{array}$ & $\begin{array}{r}-0.005 \\
(0.011)\end{array}$ & $\begin{array}{l}-0.048 \\
(0.052)\end{array}$ & $\begin{array}{r}-0.291^{* * *} \\
(0.072)\end{array}$ \\
\hline R-square & 0.259 & 0.309 & 0.339 & 0.208 & 0.874 & 0.885 \\
\hline Observations & 713 & 696 & 696 & 80 & 80 & 80 \\
\hline Number of Bank & 104 & 104 & 104 & 12 & 12 & 12 \\
\hline
\end{tabular}

ROA denotes return on asset, VAIC denotes value-added intellectual capital, LLP denotes loan loss provision, LOANTA denotes loan to total asset, CAP denotes equity to total asset, LnTA denotes natural logarithm of total asset, GrGdp denotes growth of the gross domestic product, and INF denotes inflation rate. Asterisk $\left({ }^{* * *}\right),\left({ }^{* *}\right)$ and $(*)$ indicate statistically significant at $1 \%, 5 \%$, and $10 \%$ significance level. Figures in the round $($.$) brackets$ are a robust standard error while the value above it is coefficient value. 
factor in creating profitability. Based on all the empirical analysis that we conducted, we can conclude human capital is the most important component of intellectual capital in Islamic and conventional banks. Second, conventional banks have the ability in organizing and collaborating intellectual capital components to generate profitability better than Islamic banks.

Our contribution in this study reveals the lack of Indonesia Islamic banking in managing its intel- lectual capital. This study is relatively new, especially in Indonesia, even in South East Asia, since most of the previous literature only focus on one specific type of bank or never compare it to another type of banks (Ghosh \& Mondal, 2012, Ousama \& Fatima, 2015; Nawaz \& Haniffa, 2017). We believe that studies which directly compares the intellectual capital between Islamic banks and conventional banks are very limited. Thus, our study fills this gap. In addition, this study also contributes to the

Table 5. Regression result: the effect of VAIC component on bank profitability

\begin{tabular}{|c|c|c|c|c|c|c|}
\hline \multirow[b]{2}{*}{ Variables } & \multicolumn{3}{|c|}{$\begin{array}{c}\text { Conventional \& Islamic Banks } \\
\text { Fixed Effect }\end{array}$} & \multicolumn{3}{|c|}{$\begin{array}{c}\text { Conventional \& Islamic Banks } \\
\text { OLS }\end{array}$} \\
\hline & $\begin{array}{c}(1) \\
\text { ROA }\end{array}$ & $\begin{array}{c}(2) \\
\text { ROA }\end{array}$ & $\begin{array}{c}(3) \\
\text { ROA }\end{array}$ & $\begin{array}{c}(4) \\
\text { ROA }\end{array}$ & $\begin{array}{c}(5) \\
\text { ROA }\end{array}$ & $\begin{array}{c}(6) \\
\text { ROA }\end{array}$ \\
\hline HCE & $\begin{array}{r}0.007^{* * *} \\
(0.001)\end{array}$ & $\begin{array}{r}0.007^{* * *} \\
(0.001)\end{array}$ & $\begin{array}{r}0.006^{* * *} \\
(0.001)\end{array}$ & $\begin{array}{r}0.005^{* * *} \\
(0.001)\end{array}$ & $\begin{array}{r}0.005^{* * *} \\
(0.001)\end{array}$ & $\begin{array}{r}0.004^{* * *} \\
(0.001)\end{array}$ \\
\hline SCE & $\begin{array}{r}-0.000 \\
(0.000)\end{array}$ & $\begin{array}{r}-0.000 \\
(0.000)\end{array}$ & $\begin{array}{r}-0.000 \\
(0.000)\end{array}$ & $\begin{array}{r}0.000 \\
(0.001)\end{array}$ & $\begin{array}{r}0.000 \\
(0.001)\end{array}$ & $\begin{array}{r}0.000 \\
(0.001)\end{array}$ \\
\hline CEE & $\begin{array}{r}-0.001 \\
(0.001)\end{array}$ & $\begin{array}{r}-0.001 \\
(0.001)\end{array}$ & $\begin{array}{r}-0.001 \\
(0.001)\end{array}$ & $\begin{array}{r}0.003 \\
(0.003)\end{array}$ & $\begin{array}{r}0.003 \\
(0.003)\end{array}$ & $\begin{array}{r}0.003 \\
(0.003)\end{array}$ \\
\hline LLP & & $\begin{array}{l}-0.092 \\
(0.087)\end{array}$ & $\begin{array}{r}-0.090 \\
(0.082)\end{array}$ & & $\begin{array}{r}-0.124^{* *} \\
(0.058)\end{array}$ & $\begin{array}{r}-0.129 * * \\
(0.057)\end{array}$ \\
\hline LOANTA & & $\begin{array}{r}-0.002 \\
(0.009)\end{array}$ & $\begin{array}{r}0.002 \\
(0.008)\end{array}$ & & $\begin{array}{r}-0.015^{\star * *} \\
(0.005)\end{array}$ & $\begin{array}{r}-0.010^{* *} \\
(0.005)\end{array}$ \\
\hline CAP & & $\begin{array}{r}0.009 \\
(0.008)\end{array}$ & $\begin{array}{c}0.026^{* *} \\
(0.012)\end{array}$ & & $\begin{array}{c}-0.014^{*} \\
(0.008)\end{array}$ & $\begin{array}{r}-0.009 \\
(0.008)\end{array}$ \\
\hline LnTA & & $\begin{array}{r}-0.003^{* *} \\
(0.001)\end{array}$ & $\begin{array}{r}0.003 \\
(0.002)\end{array}$ & & $\begin{array}{c}0.001^{*} \\
(0.000)\end{array}$ & $\begin{array}{r}0.001^{* * *} \\
(0.000)\end{array}$ \\
\hline GrGDP & & & $\begin{array}{c}0.562^{* * *} \\
(0.168)\end{array}$ & & & $\begin{array}{r}0.464^{* * *} \\
(0.097)\end{array}$ \\
\hline INF & & & $\begin{array}{r}0.019 \\
(0.012)\end{array}$ & & & $\begin{array}{r}0.029 \\
(0.019)\end{array}$ \\
\hline Constant & $\begin{array}{l}-0.004 \\
(0.003)\end{array}$ & $\begin{array}{c}0.046^{* *} \\
(0.018)\end{array}$ & $\begin{array}{c}-0.087^{*} \\
(0.050)\end{array}$ & $\begin{array}{r}0.001 \\
(0.002)\end{array}$ & $\begin{array}{r}0.004 \\
(0.007)\end{array}$ & $\begin{array}{r}-0.033^{* * *} \\
(0.010)\end{array}$ \\
\hline R-square & 0.609 & 0.656 & 0.676 & 0.357 & 0.438 & 0.459 \\
\hline $\begin{array}{l}\text { Observations } \\
\text { Number of } \\
\text { Bank }\end{array}$ & 776 & 776 & 776 & 776 & 776 & 776 \\
\hline
\end{tabular}

ROA denotes return on asset, HCE denotes human capital efficiency, SCE denotes structural capital efficiency, CEE denotes capital employed efficiency, LLP denotes loan loss provision, LOANTA denotes loan to total asset, CAP denotes equity to total asset, LnTA denotes natural logarithm of total asset, GrGdp denotes growth of gross domestic product, and INF denotes inflation rate. Asterisk $\left({ }^{* * *}\right),\left({ }^{* *}\right)$ and $(*)$ indicate statistically significant at $1 \%, 5 \%$, and $10 \%$ significance level. Figures in the round (.) brackets are a robust standard error while the value above it is coefficient value 
body of knowledge by showing the importance of intellectual capital in generating value creation.

\section{Conclusion, Limitations, and Suggestions Conclusion}

In this study, we have provided empirical evidence of the contribution of intellectual capital and its component on bank performance by considering the differences type of bank. Using panel data, intellectual capital plays a pivotal role in creating bank profitability. However, it is only effective in conventional banking. When intellectual capital is decomposed into sub-component, human capital has a positive effect on both bank profitability. Based on those results, we can conclude that human capital is the most dominant component of intellectual capital that helps in generating bank profitability, both in conventional or Islamic banks. However, Islamic banks lack ability in synergizing human capital, structural capital and employed capital to create profitability.

Table 6. Split sample regression result: the effect of VAIC component on bank profitability

\begin{tabular}{|c|c|c|c|c|c|c|}
\hline \multirow[b]{2}{*}{ Variables } & \multicolumn{3}{|c|}{$\begin{array}{c}\text { Conventional Banks } \\
\text { Fixed Effect } \\
\end{array}$} & \multicolumn{3}{|c|}{$\begin{array}{l}\text { Islamic Banks } \\
\text { Fixed Effect }\end{array}$} \\
\hline & $\begin{array}{c}(1) \\
\text { ROA }\end{array}$ & $\begin{array}{c}(2) \\
\text { ROA }\end{array}$ & $\begin{array}{c}(3) \\
\text { ROA }\end{array}$ & $\begin{array}{c}(4) \\
\text { ROA }\end{array}$ & $\begin{array}{c}(5) \\
\text { ROA }\end{array}$ & $\begin{array}{c}(6) \\
\text { ROA }\end{array}$ \\
\hline HCE & $\begin{array}{r}0.006^{* * *} \\
(0.001)\end{array}$ & $\begin{array}{r}0.006^{* * *} \\
(0.001)\end{array}$ & $\begin{array}{r}0.006^{* * *} \\
(0.001)\end{array}$ & $\begin{array}{r}0.008^{* * *} \\
(0.002)\end{array}$ & $\begin{array}{r}0.005^{* * *} \\
(0.001)\end{array}$ & $\begin{array}{r}0.005^{* * *} \\
(0.001)\end{array}$ \\
\hline SCE & $\begin{array}{r}0.000 \\
(0.001)\end{array}$ & $\begin{array}{r}0.000 \\
(0.000)\end{array}$ & $\begin{array}{r}0.000 \\
(0.000)\end{array}$ & $\begin{array}{r}0.000 \\
(0.000)\end{array}$ & $\begin{array}{r}-0.000 \\
(0.000)\end{array}$ & $\begin{array}{r}-0.000 \\
(0.000)\end{array}$ \\
\hline CEE & $\begin{array}{r}-0.001 \\
(0.001)\end{array}$ & $\begin{array}{r}-0.000 \\
(0.001)\end{array}$ & $\begin{array}{r}-0.000 \\
(0.001)\end{array}$ & $\begin{array}{r}0.260 \\
(0.194)\end{array}$ & $\begin{array}{r}0.131 \\
(0.074)\end{array}$ & $\begin{array}{r}0.112 \\
(0.085)\end{array}$ \\
\hline LLP & & $\begin{array}{r}-0.008 \\
(0.048)\end{array}$ & $\begin{array}{r}-0.010 \\
(0.045)\end{array}$ & & $\begin{array}{r}-0.221^{* * *} \\
(0.017)\end{array}$ & $\begin{array}{r}-0.214^{* * *} \\
(0.026)\end{array}$ \\
\hline LOANTA & & $\begin{array}{r}0.008 \\
(0.009)\end{array}$ & $\begin{array}{r}0.011 \\
(0.009)\end{array}$ & & $\begin{array}{l}-0.012^{*} \\
(0.006)\end{array}$ & $\begin{array}{r}-0.009 \\
(0.006)\end{array}$ \\
\hline CAP & & $\begin{array}{r}0.001 \\
(0.007)\end{array}$ & $\begin{array}{l}0.015^{*} \\
(0.009)\end{array}$ & & $\begin{array}{r}0.031 \\
(0.018)\end{array}$ & $\begin{array}{r}0.034 \\
(0.024)\end{array}$ \\
\hline LnTA & & $\begin{array}{r}-0.004^{* * *} \\
(0.001)\end{array}$ & $\begin{array}{r}0.001 \\
(0.002)\end{array}$ & & $\begin{array}{r}0.004 \\
(0.002)\end{array}$ & $\begin{array}{r}0.007 \\
(0.004)\end{array}$ \\
\hline GrGDP & & & $\begin{array}{r}0.440^{* * *} \\
(0.139)\end{array}$ & & & $\begin{array}{r}0.452 \\
(0.252)\end{array}$ \\
\hline INF & & & $\begin{array}{c}0.024^{* *} \\
(0.011)\end{array}$ & & & $\begin{array}{r}-0.066^{* *} \\
(0.024)\end{array}$ \\
\hline Constant & $\begin{array}{r}-0.000 \\
(0.002)\end{array}$ & $\begin{array}{r}0.057^{* * *} \\
(0.017)\end{array}$ & $\begin{array}{r}-0.050 \\
(0.041)\end{array}$ & $\begin{array}{r}-0.021^{* * *} \\
(0.004)\end{array}$ & $\begin{array}{r}-0.061 \\
(0.040)\end{array}$ & $\begin{array}{r}-0.141 \\
(0.085)\end{array}$ \\
\hline R-square & 0.499 & 0.527 & 0.550 & 0.901 & 0.974 & 0.979 \\
\hline Observations & 696 & 696 & 696 & 80 & 80 & 80 \\
\hline Number of Bank & 104 & 104 & 104 & 12 & 12 & 12 \\
\hline
\end{tabular}


Based on the previous study, our finding is different from Ousama \& Fatima (2015) which found that intellectual capital has a positive effect on Malaysia Islamic bank profitability. We expect the inability of Indonesia Islamic bank in managing intellectual capital compared to Malaysia Islamic bank because Islamic banking in Indonesia is not as mature as Malaysia. In addition, Malaysia Islamic banking is bigger than in Indonesia Islamic banking. Having superior lending capacity may help the organization to accumulate more experiences and better able to invest their fund (Delis, Kokas, \& Ongena, 2017)

Our analysis may have important implications for managers. Our study can be a critique for Indonesia banking industry, especially Islamic banks. The performance of Islamic banks is less than conventional banks. Compared to conventional banks, the level of intellectual capital in the Islamic bank is severe. Our results also indicate conventional banks have better ability in managing its intellectual capital to create profit. In this paper, we suggest that Islamic banks should learn how to manage their intellectual capital well. They could learn to its counterpart, conventional banks. Another solution, they can hire experienced employee from former conventional banks to introduce the culture and method of how intellectual capital is organized.

\section{Limitations and suggestions}

We are aware that our study has a weakness since it is only conducted using only Indonesia data. This weakness would raise a question about whether other countries experience a similar condition. Thus, further research should be used to cross countries data. For the future research, it could expand the data by adding other countries. In addition, future research should not be limited only in the quantitative approach. The qualitative method could be conducted to investigate why Indonesia Islamic banks lack ability in managing intellectual capital. Study of intellectual capital can be also expanded to analyze other financial institution such as insurance companies and investment trusts. Indeed, comparing to other financial institution, the banking industry is still the most essential in Indonesia. However, they have a similar characteristic in using intangible assets for its operation.

\section{Acknowledgment}

Thank you for Mr. Akhmad Akbar Susamto for giving us a suggestion in completing this article.

\section{References}

Bayburina, E., \& Golovko, T. (2009). Design of sustainable development: Intellectual value of large BRIC companies and factors of their growth. Electronic Journal of Knowledge Management, 7(5), 535-558.

Bontis, N. (1999). Managing organizational knowledge by diagnosing intellectual capital: framing and advancing the state of the field. International Journal of Technology Management, 18(5), 433-463. https://doi.org/10.1504/ijtm.1999.002780

Chahal, H., \& Bakshi, P. (2016). Measurement of intellectual capital in the Indian banking sector. The Journal for Decision Makers, 41(1), 61-73. https://doi.org/10.1177/0256090916629253

Demirguc-Kunt, A., \& Huizinga, H. (2000). Financial structure and bank profitability. World Bank Policy Research Working Paper No. 2430. https://doi.org/10.1596/1813-9450-2430

Delis, M. D., Kokas, S., \& Ongena, S. (2017). Bank market power and firm performance. Review of Finance, 21(1), $299-326$. https://doi.org/10.1093/rof/rfw004 
Garcia-Meca, E., \& Martinez, I. (2005). Assessing the quality of disclosure on intangibles in the Spanish Capital Market. European Busines Review, 17(4), 305-313. https://doi.org/10.1108/09555340510607352

Goddard, J.A., Molyneux, P.M., \& Wilson, J.O.S. (2004). Dynamics of growth and profitability in banking. Journal of Money, Credit, and Banking, 36(6), 1069-1090. https://doi.org/10.1353/mcb.2005.0015

Khairiyansyah, K., \& Vebtasvili, V. (2018). Relationship between intellectual capital with profitability and productivity in Indonesian banking industry. Jurnal Keuangan Perbankan, 22(1), 127-136. https://doi.org/10.26905/jkdp.v22i1.1577

Khan, H., \& Ali Mohobbot, M. (2010). An empirical investigation and users' perceptions on intellectual capital reporting banks. Journal of Human Resource Costing and Accounting, 14(1), 48-69. https://doi.org/10.1108/14013381011039799

Le, T.P.V., \& Phan, T.B.N. (2017) Capital structure and firm performance: empirical evidence from small transition country. Research in International Business and Finance, 42, 710-726. https://doi.org/10.1016/j.ribaf.2017.07.012

Meles. A., Porzio, C., Sampagnaro, G., \& Verdoliva. V. (2016). The impact of intellectual capital efficiency on commercial banks performance: Evidence from The US. Journal of Multinational Financial Management, 36, 64-74. https://doi.org/10.1016/j.mulfin.2016.04.003

Menicucci, E., \& Paolucci, G. (2016). The determinants of bank profitability: Empirical evidence from European banking sector. Journal of Financial Reporting and Accounting, 14(1), 86-115. https://doi.org/10.1108/jfra-05-2015-0060

Mondal, A., \& Ghosh, S. K. (2012). Intellectual capital and financial performance of Indian banks. Journal of Intellectual Capital, 13(4), 515-530. https://doi.org/10.1108/14691931211276115

Nawaz, T., \& Haniffa, R. (2017). Determinants of financial performance of Islamic banks: An intellectual capital perspective. Journal of Islamic Accounting and Business Research, 8(2), 130-142. https://doi.org/10.1108/jiabr-06-2016-0071

Ousama, A. A., \& Fatima, A. H. (2015). Intellectual capital and financial performance of Islamic banks. International Journal of Learning and Intellectual Capital, 12(1), 1-15. https://doi.org/10.1504/ijlic.2015.067822

Ozkan, N., Cakan, S., and Kacayan, M. (2017). Intellectual capital and financial performance: A study of the Turkish Banking Sector. Borsa Istanbul Review, 17(3), 190-198. https://doi.org/10.1016/j.bir.2016.03.001

Pulic, A. (1998). Measuring the performance of intellectual potential in knowledge economy. Presented in the $2^{\text {nd }}$ McMaster World Congress on Measuring and Managing Intellectual Capital.

Puntillo, P. (2009). Intellectual capital and business performance. Evidence from Italian banking industry. Electronic Journal of Corporate Finance, 4(12), 97-115.

Rehman, W., Rehman, H., Usman, M., \& Ashgar, N. (2012). A link of intellectual capital performance with corporate performance: Comparative study from banking sector in Pakistan. International Journal of Business and Social Science, 3(12), 313-321.

Shaban, M., Duygun, M., Anwar, M., \& Akbar, B. (2014). Diversification and banks' willingness to lend to small business: Evidence from Islamic and conventional banks in Indonesia. Journal of Economic Behavior and Organization. 103, 539-555. https://doi.org/10.1016/j.jebo.2014.03.021

Shaikh, S. A. (2014). Analysis of challenges and opportunities in Islamic banking. International Journal of Financial Services, 7, 286-300. https://doi.org/10.1504/ijfsm.2014.065581

Sufian, F., \& Chong, R. R. (2008). Determinants of bank profitability in a developing economy: Empirical evidence from Philipines. Asian Academy of Management Journal of Accounting and Finance, 4(2), 91-112. 


\section{Intellectual capital and bank profitability: Evidence from conventional and Islamic bank in Indonesia}

Danes Quirira Octavio, Yuli Soesetio

Susamto, A. A. (2018). Toward a new framework of Islamic economic analysis. Universitas Gadjah Mada Working Papers on Islamic Economics and Finance, 1(2).

Tan, Y., \& Floros, C. (2012). Bank profitability and inflation: The case of China. Journal of Economic Studies, 39(6), 675-696. https://doi.org/10.1108/01443581211274610

Ting, I. W. K., \& Lean, H. H. (2009). Intellectual capital performance of financial institutions in Malaysia. Journal of Intellectual Capital, 10(4), 588-599. https://doi.org/10.1108/14691930910996661 